\title{
Effect of photoperiod on ovarian maturation in Cheirodon interruptus (Teleostei: Characidae)
}

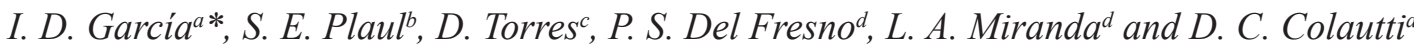 \\ aLaboratorio de Ecología de Peces, Instituto de Limnología "Dr. Raúl A. Ringuelet" - ILPLA/ CONICET-UNLP, \\ Boulevard 120 y 62, 1460, CP 1900, CC 712, La Plata, Buenos Aires, Argentina \\ ${ }^{b}$ Laboratorio de Histología y Embriología Descriptiva, Experimental y Comparada, \\ Facultad de Ciencias Veterinarias - UNLP, Av. 60 y 118, La Plata, Buenos Aires, Argentina \\ 'Ministerio de Agroindustria, Subsecretaría de Pesca y Acuicultura de la Nación, Dirección de Pesca Continental, \\ Paseo Colón 982, 1073, Buenos Aires, Argentina \\ ${ }^{\text {d} L a b o r a t o r i o ~ d e ~ I c t i o f i s i o l o g i ́ a ~ y ~ A c u i c u l t u r a, ~ I n s t i t u t o ~ d e ~ I n v e s t i g a c i o n e s ~ B i o t e c n o l o ́ g i c a s-I n s t i t u t o ~ T e c n o l o ́ g i c o ~ d e ~}$ \\ Chascomús “Dr. Raúl Alfonsín” - IIB-INTECH/ CONICET-UNSAM, Intendente Marino, Km 8.200 (B7130IWA), \\ Chascomús, Buenos Aires, Argentina \\ *e-mail: igarcia@ilpla.edu.ar; ignadgarcia@gmail.com.ar
}

Received: December 01, 2017 - Accepted: March 08, 2018 - Distributed: November 30, 2019

(With 2 figures)

\begin{abstract}
Cheirodon interruptus is a ubiquitous small characid that inhabits the Pampean region and commonly used as bait. Its vast market is supplied from the wild population causing a significant environmental impact. In this study, we assess the effect of photoperiod on ovarian maturation in order to evaluate its potential as a tool to manipulate reproduction under artificial conditions. Four treatments in triplicate (light: dark, L: D) were tested: 24L: 0D, 12L: 12D, 0L: 24D and a progressive photoperiod corresponding to the daily photoperiod increments in wild during winter-spring transition, accelerated three times. The experiment was conducted for 45 days. Gonadosomatic index (GSI), oocyte mean diameter, vitellogenic oocyte proportions, plasma estradiol concentrations (E2), condition factor (Kn) and standard length were estimated. Values of mean GSI, oocyte diameter, vitellogenic oocyte proportions and E2 concentration were maximum in the progressive treatment indicating vitellogenesis stimulation. In turn the same parameters were minimum in the 24L: $0 \mathrm{D}$, revealing the vitellogenesis inhibition. This study showed that photoperiodic regime play an important role in the onset of ovarian maturation in C. interruptus.
\end{abstract}

Keywords: photoperiod, gonadal maturation, vitellogenesis, Characiforms.

\section{Efeito do fotoperíodo na maturação dos ovários em Cheirodon interruptus (Teleostei: Characidae)}

\section{Resumo}

Cheirodon interruptus é um pequeno caracídeo amplamente distribuído na região Pampeana e comumente usado como isca. Seu vasto mercado se abastece de populações silvestres causando um impacto ambiental significativo. Neste estudo, investigamos o efeito do fotoperíodo no amadurecimento do ovário para avaliar o potencial deste fator como ferramenta para manipular a reprodução em condições artificiais. Quatro tratamentos foram testados por triplicado (luz: escuro, L: D): 24L: 0D, 12L: 12D, 0L: 24D e um fotoperíodo progressivo que simula as mudanças das horas luz na natureza e na transição de inverno a primavera, acelerado três vezes. O experimento se realizou durante 45 dias. O índice gonadossomático (GSI), o diâmetro médio dos ovócitos, a proporção de ovócitos vitelogênicos, as concentrações plasmáticas de estradiol (E2), o fator de condição (Kn) e o comprimento padrão foram estimados. Os valores médios de GSI, o diâmetro dos ovócitos, as proporções de ovócitos vitelogênicos e a concentração de E2 foram maximizados no fotoperíodo progressivo, indicando estimulação de vitelogênesis. Por outro lado, esses mesmos parâmetros resultaram mínimos no tratamento 24L: 0D, revelando um efeito inibidor da vitelogênesis. Este estudo mostrou que as variações de fotoperíodo exercem um papel importante no início vitelogênesis reprodutiva em C. interruptus.

Palavras-chave: fotoperíodo, maturação gonadal, vitelogênese, Characiformes. 


\section{Introduction}

Cheirodon interruptus (Jennyns 1842) is a small fish widely spread in South America: Argentina, Brazil, Chile (introduced) and Uruguay, belongs to Characiforms order which is extensively represented in the Neotropical region. Because $C$. interruptus is a species highly resistant to captivity, is used as bait in the Odontesthes bonariensis (Valenciennes, 1835) recreational fishing, involving about 2 million of fishermen only in Buenos Aires Province (Grosman, 2001). In addition, this species could be a promising experimental model for its use in environmental toxicology due to fulfill the requirements of sensitivity (Hued and Bistoni, 2005; Bonifacio et al., 2017) wide distribution, abundance in the environment and high resistance to manipulation (Campana et al., 1999). Extraction of this species, to supply this vast market, is carried out with fine mesh trawls, causing an impact on fish communities and a physical and biological deterioration in streams, shallow lakes or wetlands. In spite of the relevance of the species sale and its potential experimental value, research on its breeding is very scarce (Maiztegui et al., 2009) and information about their biology is also limited (Sendra and Freyre, 1981a, b; Escalante, 1983, 1987; Lopez Cazorla and Sidorkewicj, 2005; Ferriz et al., 2011). Sendra and Freyre (1981a) have described an annual cycle, with a marked spawning period in late winter and spring (August-November), and an eventual reproductive peak of lower intensity in autumn (March-April). The same authors also documented that during the longest and hottest days of summer (January - February) the gonads were arrested.

It is a known matter that fish life activities are influenced by seasonality, particularly in temperate and cold climates where the photoperiod range changes along the year are greater and has a relevant influence on fish biology (Pankhurst and Porter, 2003). According to Ginés et al., (2004) and Biswas et al., (2010), photoperiod is an important environmental factor that directly or indirectly affects fish growth, feeding, locomotory activity, metabolic rates, body pigmentation, sexual maturity and reproduction. Moreover, despite that a number of environmental factors have been implicated as possible responsible for the cueing and timing of reproduction in the majority of fish, the seasonal pattern of day length change, is probably the primary factor in the regulation of gonadal maturation process (Bromage et al., 2001).

The effect of photoperiod on gonadal development and reproduction on fish is mediated by endogenous rhythms and sex hormones synthesis and secretion (Elisio et al., 2014, 2015). For most fish species with marked seasonality of breeding activity, the timing and duration of photoperiod treatment are critical for manipulating the process of sexual maturity (Zhu et al., 2014) and therefore could be altered by compressing or extending the yearly photoperiod cycle (Bromage et al., 2001). There are few studies about the relationship between photoperiod and gonadal maturation in $C$. interruptus cohabitants fish species from temperate climates. For instance, in Odontesthes bonariensis the increase in day length, triggers the ovarian maturation of females after the winter period of gonadal rest (Miranda et al., 2009). Also, in an exotic fish Cyprinus carpio, Linnaeus, 1758 , gonadal maturation requires increasing photoperiod (Kucharczyk et al., 2008). Meanwhile the effect of photoperiod on ovarian maturation in Characiforms is less known, but there are several studies on wild populations that showed significant correlations between the increase of photoperiod and gonadal development (Azevedo et al., 2000; Lampert et al., 2007; Oliveira et al., 2010).

Many studies have demonstrated that, under controlled conditions, photoperiod regulation could be used as a reliable tool for manipulate reproduction in several fish species. Indeed, the use of artificial photoperiods, have had a crucial role in the development of rearing techniques for numerous species in laboratory or under different culture conditions. As instances, could be mentioned the delay in gonadal maturation, through studies of gonadosomatic index, in tilapia (Rad et al., 2006) and perch (Migaud et al., 2004) by means of permanent illumination. The stimulation to maximum fecundity in tilapia by exposition to $12: 12$ illumination regime (El-Sayed and Kawanna, 2007). The delay of ovarian maturation in topmouth gudgeon in short photoperiods and absolute darkness or its stimulation when were exposed to long photoperiods (18 to 24 light hours day ${ }^{-1}$ ) (Zhu et al., 2014). The advance of gonadal maturation by compression of the natural annual photoperiod cycle in Atlantic cod (Norberg et al., 2004). This few examples show that different artificial photoperiod regimes, could have the same or different effect over the fish reproductive biology, depending on the species to they belongs. Whatever the response to photoperiod treatment, the knowledge of its effect on gonadal development, is a prerequisite to develop management guidelines for species in captivity.

Because of the importance of $C$. interruptus as bait, its potential use as experimental fish, and the necessity to protect the species and its environment from the threat of intensive extraction, it is important to understand the reproductive biology of this species. Therefore, this study analyzes the influence of different artificial photoperiod regimes on the ovaries of $C$. interruptus to evaluate the potential of photoperiod as a tool to manipulate reproductive cycle in the species.

\section{Materials and Methods}

On June 20, 2015, a total of 480 adults of Cheirodon interruptus (standard length $3.68+/-0.24 \mathrm{~cm}$; body weight $1.24+/-0.37 \mathrm{~g}$ ) were collected from artificial ponds located in Chascomús County, Buenos Aires, Argentina $\left(-35^{\circ} 54^{\prime} \mathrm{S}-58^{\circ} 11^{\prime} \mathrm{W}\right)$. The photoperiod was set on a 12-hour cycle in the last three weeks before the experiment.

During the acclimatization and the experiment, the variation of water temperature, dissolved oxygen and conductivity were kept under narrow ranges and checked five times a week to make adjustments if necessary. The mean values and the standard deviations of the referred 
variables were temperature $\left(20^{\circ} \mathrm{C} \pm 1{ }^{\circ} \mathrm{C}\right)$, dissolved oxygen $(7.5 \pm 0.5 \mathrm{mg} / \mathrm{L})$ and conductivity $(1048 \pm 60 \mu \mathrm{S})$. The $\mathrm{N}-\mathrm{NH}_{4}^{+}$and $\mathrm{N}-\mathrm{NO} 2^{-}$levels were measured weekly with indophenol blue and sulphanilamide methods, respectively. The values remained between 0.0 and $0.1 \mathrm{mg} / \mathrm{L} \mathrm{N}-\mathrm{NH}^{+}$ and below $0.4 \mathrm{mg} / \mathrm{L} \mathrm{N}-\mathrm{NO} 2^{-}$. Fish were hand-fed with a commercial food (Shulet ${ }^{\circledR}$, Argentina) containing $\geq 44.0 \%$ crude protein, $\geq 5.0 \%$ crude fibre, $\geq 10 \%$ total fat, total minerals $\geq 12 \%$, and $\leq 6 \%$ moisture. Food was offered three times a day, six days a week (ad-libitum) at 09:00, 13:00 and 17:00.

The experiment was conducted in a recirculation system with twelve $50 \mathrm{~L}$ aquaria where each one of them was drained into a $150 \mathrm{~L}$ wet-dry filter (lower reservoir tanks) containing $35 \mathrm{~L}$ of Bioball Substrate, and a macro-porous synthetic polymer (Purigen ${ }^{\circledR}$ ). Subsequently, the water was raised by pumps, level dependently, to upper tanks and then to individual aquariums. The water flow from the upper tanks to each aquarium was controlled by a valve in the inlet pipes and the level was fixed by an upper drainage outlet with pipe connected to the lower reservoirs. The recirculation rate was $20 \mathrm{~L} / \mathrm{h}$ and 20 percent of the water was renewed weekly when tanks were siphoned to remove wastes from the bottom. Each aquarium was fully isolated from the external light with a double opaque cover and individually illuminated by the installation of a led system connected to microcontrollers (atmega328 Arduino) capable of controlling light hours and intensity.

To assess and compare gonadal induced changes in C. interruptus under different photoperiods, four light regimes were used with three replicates for each treatment (light: dark, L: D): 24L: 0D, 12L: 12D (as control) 0L: 24D and a progressive. photoperiod that responds to the function of light day hours changes observed in the transition winter-spring at the latitude of the place where the specimens were captured, starting from the photoperiod of the winter solstice (9.8L: 14.2D), and applying daily increases corresponding to the sum of that observed in three successive days in the environment until reach the light-hours observed at the spring equinox (13.3L: 10.7D) (See Figure 1). At the transitions of $\mathrm{D}$ to $\mathrm{L}$ and $\mathrm{L}$ to $\mathrm{D}$, the light intensity was gradually changed, simulating the sunrise and sunset for one hour. The light intensity was maintained at $105 \mathrm{~lx}$ on the water surface during the light phase and $0 \mathrm{~lx}$ during the dark phase.

Thirty females were anesthetized with benzocaine (100 ppm) and then sacrificed by transecting the spinal cord to examine the initial gonad condition. Thirty females and ten males were placed in each tank. The experiment was conducted for 45 days.

At the end of the experiment, all fish were sacrificed following the protocols described above. They were counted for survival percent estimation and the standard length and weight of all specimens were recorded.

Blood samples were taken from the caudal artery and were collected with syringes in $2 \mathrm{ml}$ plastic vials. On average, 15-20 females were pooled from each replicate to obtain the amount of plasma required for analysis. Plasma was separated by centrifugation at $3000 \mathrm{rpm}$ for $15 \mathrm{~min}$ and stored at $-80^{\circ} \mathrm{C}$ until used to measure sexual steroids.

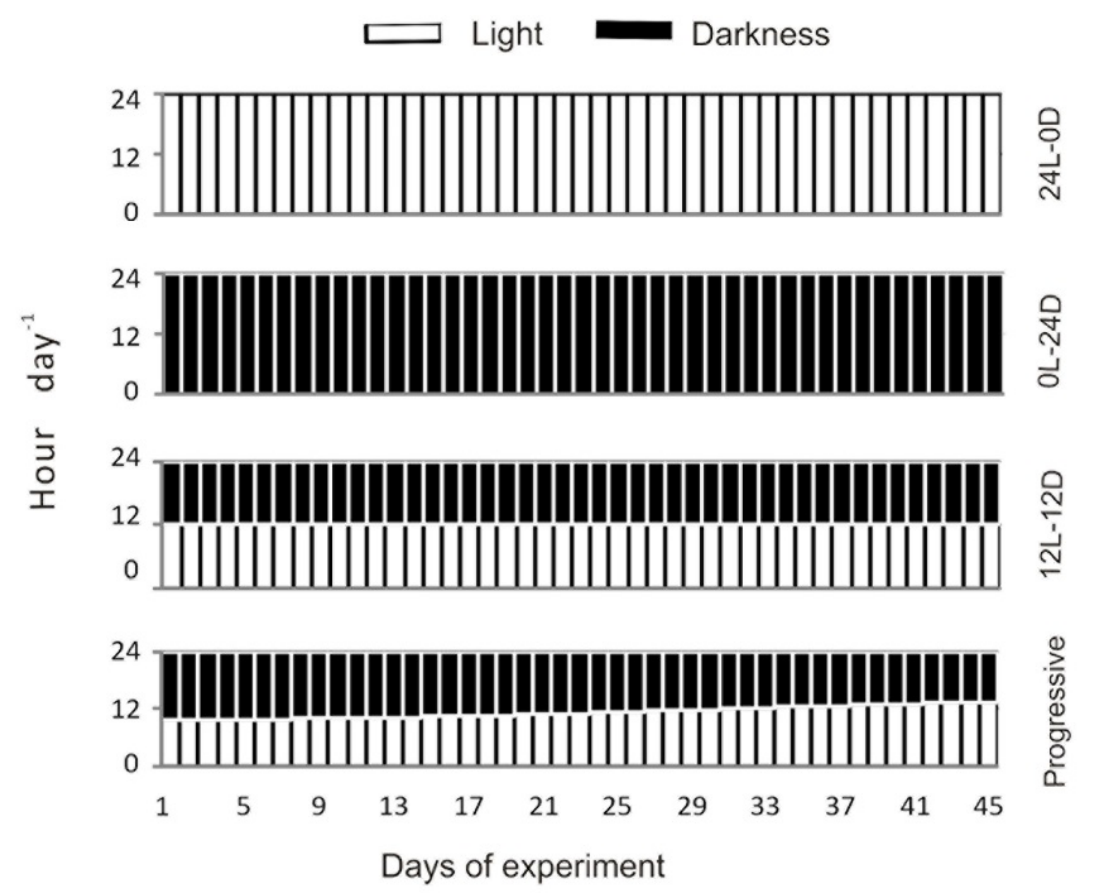

Figure 1. Light and darkness daily regimes in each treatment during the 45 days of experiment. 
The ovaries were removed and weighed with an analytic scale $(0.0001 \mathrm{gr})$ and fixed by immersion in formalin 5\%. The gonadosomatic index (GSI) (GSI= gonad weight $\times 100$ /body weight) for females was calculated.

For histological analysis, gonads from randomly selected females were used, 24 (eight by replica) from the progressive photoperiod, five of initial condition and 15 (five by replica) for the rest of the treatments. Samples were routinely processed and embedded in paraffin wax. Histological sections were obtained using a sledge microtome, prepared according to the standard protocol, and then stained using the hematoxylin and eosin (H\&E) technique. Each glass slide was examined under a light microscope connected to a video camera (Tucsen ISH 500). Total oocytes from two slides per fish were classified and counted. Proportions of vitellogenic and previtellogenic oocytes were established. Furthermore, the oocyte samples were photographed using ISCapture 3.7.5 versions and measured according to the following formula: Oocyte diameter $\mathrm{mm}=($ long axis length + short axis length $) / 2$. The oocyte mean diameter and standard deviations for each treatment were calculated.

Estradiol plasma levels were measured by an enzyme-linked immunosorbent assay (ELISA) based on the principle of competitive binding, using commercial kits and following the manufacturer's protocols (DRG International Inc., Mountainside, NJ, USA; E2: EIA-2693) previously validated by Chalde et al. (2016). A standard curve was run for each ELISA plate. The lower limit of detection was $32.41 \mathrm{pg} / \mathrm{ml}$ for E2. The optical density was read at $450 \mathrm{~nm}$, for both T and E2. The intra-assay coefficients of variance were $<10 \%$.

The relative condition factor $(\mathrm{Kn})$ of the females, which is considered the most appropriated to evaluate intra population fish welfare (Baigún et al., 2009), was calculated according Le Cren, (1951), as follows: $\mathrm{Kn}=\mathrm{W} / \mathrm{W}^{\prime}$ where $\mathrm{W}=$ observed weight and $\mathrm{W}^{\prime}$ is the length-specific mean weight for a given fish within the population as predicted by the population involved in the experiment weight-length relationship.

Gonadosomatic index (GSI), oocyte diameter and condition factor values as well as the final standard length, and weight were tested for goodness of fit to normal distribution and requirements of homogeneity of variances were also determined. Results of GSI, oocyte mean diameter, as well as, $\mathrm{Kn}$, final standard length and weight were compared among treatments by means of nonparametric methods using a Kruskal- Wallis test followed by the non-parametric all pairwise multiple comparison procedure (Dunn's method). A significance level of $\mathrm{p}=0.05$ was considered in all test procedures.

\section{Results}

At the end of the experiment, the GSI of females differed significantly $(p<0,001)$ among treatments. The pairwise multiple comparison results determined that almost all treatments differed significantly $(\mathrm{p}<0.05)$ except in the case 12L: $12 \mathrm{D}$ and $0 \mathrm{~L}: 24 \mathrm{D}$. The highest GSI mean value was obtained in the progressive group followed by the one from 0L: 24D. The lowest GSI mean value was observed in 24L: 0D. The final GSI observed in 12L: 12D was almost the same as the initial condition (See Table 1).

Histological analysis revealed significant differences $(\mathrm{p}<0.001)$ among treatments in oocyte size and the proportion of previtellogenic and vitellogenic oocytes (See Table 2).

The 24L: 0D photoperiod presented totally immature gonads with the smallest oocyte size and the highest proportion of previtellogenics oocytes were found (see Figure 2a). Under 12L: 12D females generally had undeveloped ovaries predominating in the tissue slides primary growth and cortical alveoli oocytes (see Figure $2 \mathrm{~b}$ ). The 0L: 24D photoperiod advanced gonad development of females (see Figure 2c). but presented an intermediated proportion of vitellogenics oocytes and great standard deviation. The progressive photoperiod presented the largest size and the highest proportion of vitellogenics oocytes (see Figure $2 \mathrm{~d}$ ) with the ovary predominantly filled with a large size of second yolk oocytes (see Figure 2e). It should be noted that the initial condition (see Figure 2f). was similar than 12L: 12D but they differed significantly from the 24L: 0D and progressive

The plasma concentrations of E2 showed a correlation with ovarian maturation reached in treatments. Therefore, the highest values were observed in Progressive photoperiod $(221 \pm 1.8 \mathrm{pg} / \mathrm{ml})$ followed by 0L: $24 \mathrm{D}(216.9 \pm 13.5 \mathrm{pg} / \mathrm{ml})$, and 12L: $12 \mathrm{D}(208.8 \pm 7.5 \mathrm{pg} / \mathrm{ml})$. The minimum value was recorded in the 24L: 0D treatment $(204.7 \pm 6.9 \mathrm{pg} / \mathrm{ml})$.

There were significant differences $(p<0,001)$ among treatments in terms of $\mathrm{Kn}$, standard length, and weight. The 24L: 0D photoperiod presented the best condition and the largest size, weight at the end of the experiment. It was followed by the progressive photoperiod where the condition was similar to the 24L: 0D but differed in final length and weight. The 12L: 12D and 0L: 24D treatments were similar between them but they differed significantly from the 24L: $0 D$ and progressive treatments $(\mathrm{p}<0.05)$. There was no significant difference in the survival percent of fish exposed to different treatments (See Table 3).

\section{Discussion}

This study, represents the first attempt to manipulate gonadal maturation by exposure to different photoperiod regimes in $C$. interruptus and also one of the few studies carried out in the Characiforms in the issue.

Table 1. Mean gonadosomatic index (GSI). SD: standard deviation, Min: minimum, Max: maximum, of Cheirodon interruptus, before and after exposition to different photoperiods, during the 45 days of experiment.

\begin{tabular}{lcccc}
\hline Photoperiod & GSI & SD & Min & Max \\
\hline Initial & 2.15 & 0.9 & 0.46 & 4.2 \\
Progressive & 5.04 & 2.8 & 1.89 & 16.4 \\
12L:12D & 2.71 & 1.3 & 0.76 & 5.64 \\
24L:0D & 1.61 & 0.5 & 0.71 & 3.46 \\
0D:24L & 3.27 & 2.3 & 0.21 & 12.5 \\
\hline
\end{tabular}


Table 2. Oocyte size $(\mu)$ mean, (SD) standard deviation and (\%) proportion of vitellogenic and previtellogenic oocytes, before and after exposition to different photoperiods, during the 45 days of experiment.

\begin{tabular}{|c|c|c|c|c|c|c|c|c|}
\hline & \multicolumn{4}{|c|}{ Previtellogenic } & \multicolumn{4}{|c|}{ Vitellogenic } \\
\hline & $\overline{\mathbf{X}}(\mu)$ & SD & $\mathbf{N}$ & $\%$ & $\overline{\mathbf{X}}(\mu)$ & SD & $\mathbf{N}$ & $\%$ \\
\hline Initial & 0.07 & 0.01 & 1587 & 98.3 & 0.25 & 0.09 & 28 & 1.7 \\
\hline Progressive & 0.11 & 0.035 & 6014 & 74.6 & 0.44 & 0.09 & 2047 & 25.4 \\
\hline 12L:12D & 0.097 & 0.02 & 8386 & 97.9 & 0.41 & 0.09 & 180 & 2.1 \\
\hline 24L:0D & 0.078 & 0.02 & 10782 & 99.7 & 0.23 & 0.07 & 36 & 0.3 \\
\hline 0L:24D & 0.107 & 0.038 & 5495 & 86.4 & 0.41 & 0.09 & 862 & 13.6 \\
\hline
\end{tabular}
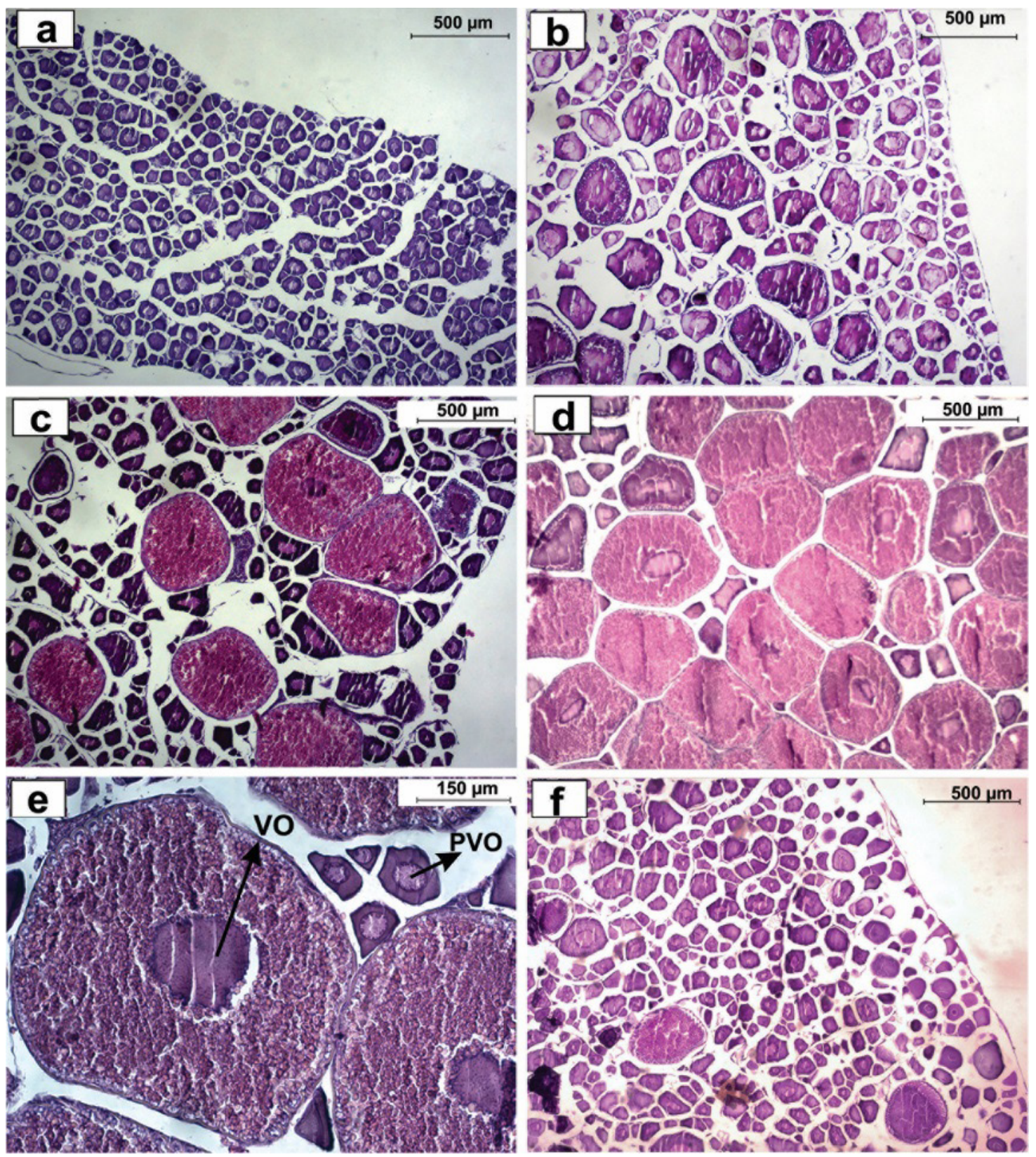

Figure 2. Histology of ovarian tissue from Cheirodon interruptus exposure to different photoperiod regimes and initial condition. a 24L: 0D. b 12L: 12D. c 0L: 24D. d. Progressive photoperiod. e. Higher magnification of progressive photoperiod showing previtellogenics oocytes (PVO) and vitellogenics oocytes (VO). f. initial condition. 
Table 3. Length (mean $\pm \mathrm{SD})$, weight ( $m e a n \pm \mathrm{SD})$, condition factor $(\mathrm{Kn})($ mean $\pm \mathrm{SD})$ and survival $(\%)$ of Cheirodon interruptus before and after exposition to different photoperiods, during the 45 days of experiment.

\begin{tabular}{ccccc}
\hline & Length $(\mathbf{c m})$ & Weight $(\mathbf{g})$ & \multicolumn{1}{c}{ Kn } & Survival (\%) \\
\hline Initial & $3.68 \pm 0.24$ & $1.24 \pm 0.37$ & $0.96 \pm 0.13$ & 0.96 \\
Progressive & $3.86 \pm 0.22$ & $1.6 \pm 0.34$ & $1.06 \pm 0.12$ & 0.99 \\
12L:12D & $3.77 \pm 0.22$ & $1.28 \pm 0.28$ & $0.92 \pm 0.07$ & 0.93 \\
24L:0D & $3.95 \pm 0.16$ & $1.72 \pm 0.22$ & $1.07 \pm 0.12$ & 0.97 \\
0L:24D & $3.84 \pm 0.26$ & $1.43 \pm 0.33$ & $0.97 \pm 0.1$ & \\
\hline
\end{tabular}

The experiment results not only indicated that photoperiods treatments can affect the ovaries development but also show different responses in the assessed reproductive parameters, according to treatment. When $C$. interruptus was exposed to permanent illumination (24L: 0D), a generalized decline in the GSI values and in vitellogenics oocytes proportion was obtained, reaching the minimal values with the lowest dispersion for the entire experiment. Both results indicate that the ovaries experienced a regression compared with initial values. The lowest levels of plasma estradiol were verified in this photoperiod treatment, indicating that the permanent illumination affects the sexual hormones segregation, generating inhibitive effects upon the vitellogenesis. This set of results agree with the observed in other species (Jourdan et al., 2000; Hansen et al., 2001; Rad et al., 2006; Taranger et al., 2006), where the absence of darkness has a generalized inhibitive effect on reproductive functions.

In turn, 12D: 12L treatment, did not induce any changes in IGS, oocyte mean diameter and vitellogenic / previtellogenic proportions from the initial state, and E2 level was intermediate. The absence of changes in the gonadal tissues in any direction is indicative that this treatment has a neutral effect on reproductive functions of the species, or at least the illumination regime is not appropriated to arrestate or activate ovaries maturation. The obtained results are opposed to such documented for Oreochromis niloticus (Linnaeus, 1758) where was observed that under $12: 12$ regime, the species spawn in a permanent way (Biswas et al., 2005).

In the case of total darkness (0L:24D) a diffuse response in terms of GSI changes was observed. The treatment showed the widest range of values variation, from ones close to the lowest, up to ones near the highest observed in the experiment. The histological results and estradiol levels were in agreement with the GSI results showing greater deviations in the vitellogenic / previtellogenic proportions among individuals. The erratic individual response to total darkness of $C$. interruptus could be interpreted as an indicative that light regime assumes a critical role in the species reproductive physiology regulation. This observation can be considered a particular trait of the reproductive biology of $C$. interruptus because in other species was proved that total darkness has delaying effects on ovarian maturation (Zhu et al., 2014).

The results in the progressive treatment support the idea that photoperiod control could promote changes toward ovarian maturation in C. interruptus because were obtained higher values of GSI than the rest of treatments. Furthermore, histological analysis in females revealed that the oocyte mean diameter and vitellogenic / previtellogenic proportion were higher in fish reared under this treatment. Values observed in the progressive treatment are in agreement with results reported for other temperate fish species in which the compression of the natural photoperiod transition from winter to spring was used to alter the gonadal development in Gadus morhua Linnaeus, 1758 (Norberg et al., 1995), Oncorhynchus mykiss (Walbaum, 1792) (Bon et al., 1999), and Latris lineata (Forster, 1801) (Morehead et al. 2000). This result suggests and reinforces the idea that daily progressive increments in day length are necessary to induce a reliable gain in $C$. interruptus gonadal weight by vitellogenesis process. In accordance with the above, steroid hormone levels were maximum in this treatment, reflecting that E2 levels were in agreement with the gonadal response in each treatment. Indeed, the progressive treatment stimulates the gonadal maturation, by the increase in ovarian mass by the uptake of vitellogenin by the oocytes in response to increased plasma E2 levels (Lubzens et al., 2010; Elisio et al., 2014).

Thus, daily progressive increments observed from winter to spring have a relevant influence in ovarian maturation and therefore light regime is an environmental driver of gonad maturation and reproduction in C. interruptus.

Although the progressive treatment promoted ovarian maturation, it is important to note that, GSI reached values were around the half of the ones observed in wild $C$. interruptus just before spawning by Ferriz et al. (2011). This suggests that likely, the compression of the winter-spring photoperiod transition in 45 days did not have enough time to completely mature the ovaries, but it allowed to confirm that this treatment is adequate to activate and sustain its maturation. Nevertheless, it is also probable that to reach the ripe state, could be necessary the influence of other triggering factor such as temperature increments, as was documented in Odontesthes bonariensis by Elisio et al. $(2014,2015)$ and Arfuso et al. (2017) in Dicentrarchus labrax (Linnaeus, 1758). Further studies should focus on the relationship between photoperiod and temperature or other variables in the gonadal response of C. interruptus in the final phase of maturation to determine if the total reproductive process can be induced by artificial regulation of culture variables. 
As additional results to the reproductive parameters, the experiment showed that the final length achieved by fish in the permanent illumination treatment was maximum. Although it is known that artificial long days seem to be involved in the enhanced somatic growth in several species Melanogrammus aeglefinus (Linnaeus, 1758) (Trippel and Neil, 2003), Oncorhynchus mykiss (Taylor and Migaud, 2009), Pagrus major (Temminck, 1843) (Biswas et al., 2005), it was never documented in C. interruptus. In fact, inhibition or delay of sexual maturation in favour of somatic growth of fish by using the constant long-day photoperiods, as was observed in this study, agrees with the found in other species, such as Sparus aurata, Linnaeus, 1758, (Kissil et al., 2001); Perca fluviatilis Linnaeus, 1758 (Migaud et al., 2004); Oreochromis niloticus (Rad et al., 2006).

If the results of progressive and 24L: 0D are analysed in terms of energy allocation, they take sense because both treatments showed the highest values of Kn, suggesting an efficient and directed use of the offered food. In simple terms progressive illumination promoted gonadal development, while the permanent light regime stimulated somatic growth. These responses of $C$. interruptus appear to be specific features of its life history traits. Indeed, according the findings obtained in this study, the photoperiod regime control should be considered as a relevant management tool in the development of culture techniques for the species. In this sense, the progressive treatment, could be used to induce cell changes in ovaries toward gonadal development in order to accelerate reproductive cycles or synchronize gamete production. Permanent illumination has the potential to be used not only to inhibit the reproductive, but also to maximize growth. Finally, 12L: 12D treatment could be considered as an adequate photoperiod to acclimatize or keep the fish minimizing the changes in their reproductive conditions. These potential applications of the study findings, represent a first contribution to understand the biology of the species focused to develop management alternatives, to alleviate the current environmental impact caused by wild populations harvesting.

\section{Acknowledgements}

This work was supported by PICT 2010 No.1579 Agencia Nacional de Promoción Científica y Tecnológica and PIP No. 0259 Consejo Nacional de Investigaciones Científicas y Técnicas (CONICET). This paper is Scientific Contribution $\mathrm{N}^{\circ} 1006$ of the Institute of Limnology "Dr. Raúl A. Ringuelet" (ILPLA, CONICET, UNLP).

\section{References}

ARFUSO, F., GUERRERA, M.C., FORTINO, G., FAZIO, F., SANTULLI, A. and PICCIONE, G., 2017. Water temperature influences growth and gonad differentiation in European sea bass. Theriogenology, vol. 88, pp. 145-151. http://dx.doi.org/10.1016/j. theriogenology.2016.09.028. PMid:27751603.
AZEVEDO, M.A., MALABARBA, L.R. and FIHALO, C.B., 2000. Reproductive biology of the inseminating Glandulocaudine Diapoma speculiferum Cope (Teleostei: Characidae). Copeia, vol. 4, no. 4, pp. 983-989. http://dx.doi.org/10.1643/00458511(2000)000[0983:RBOTIG]2.0.CO;2.

BAIGÚN, C.M., COLAUTTI, D.C. and GROSMAN, F., 2009. Assessment of condition in pejerrey Odontesthes bonariensis (Atheriniformes: Atherinopsidae) populations: which index works best? Neotropical Ichthyology, vol. 7, no. 3, pp. 439-446. http:// dx.doi.org/10.1590/S1679-62252009000300011.

BISWAS, A., INOUE, K. and TAKII, K., 2010. Feeding interval and photoperiod influence the growth performance of striped knife jaw, Oplegnathus fasciatus. Aquaculture Research, vol. 41, pp. 517-523. http://dx.doi.org/10.1111/j.1365-2109.2010.02523.x.

BISWAS, A.K., SEOKA, M., INOUE, Y., TAKII, K. and KUMAI, H., 2005. Photoperiod influences the growth, food intake, feed efficiency and digestibility of red sea bream (Pagrus major). Aquaculture (Amsterdam, Netherlands), vol. 250, no. 3-4, pp. 666-673. http://dx.doi.org/10.1016/j.aquaculture.2005.04.047.

BON, E., BRETON, B., GOVOROUN, M.S. and LE MENN, F., 1999. Effects of accelerated photoperiod regimes on the reproductive cycle of the female rainbow trout. II. Seasonal variations of plasma gonadotropins (GTH I and GTH II) levels correlated with ovarian follicle growth and egg size. Fish Physiology and Biochemistry, vol. 20, no. 2, pp. 143-154. http:// dx.doi.org/10.1023/A:1007783708432.

BONIFACIO, A.F., BALLESTEROS, M., BONANSEA, R., FILIPPI, J., AMÉ, M. and HUED, A., 2017. Environmental relevant concentrations of a chlorpyrifos commercial formulation affect two neotropical fish species, Cheirodon interruptus and Cnesterodon decemmaculatus. Chemosphere, vol. 188, pp. 486-493. http://dx.doi.org/10.1016/j.chemosphere.2017.08.156. PMid:28903091.

BROMAGE, N.R., PORTER, M.J.R. and RANDALL, C.F., 2001. The environmental regulation of maturation in farmed finfish with special reference to the role of photoperiod and melatonin. Aquaculture (Amsterdam, Netherlands), vol. 197, no. 1-4, pp. 63-98. http://dx.doi.org/10.1016/S0044-8486(01)00583-X.

CAMPANA, M.A., PANZERI, A.M., MORENO, V.J. and DULOUT, F.N., 1999. Genotoxic evaluation of the pyrethroid lambda-cyhalothrin using the micronucleus test in erythrocytes of the fish Cheirodon interruptus interruptus. Mutation Research, vol. 438, no. 2, pp. 155-161. http://dx.doi.org/10.1016/S13835718(98)00167-3. PMid:10036336.

CHALDE, T., GÁRRIZ, Á., SANCHES, E.A. and MIRANDA, L.A., 2016. Influence of pejerrey Odontesthes bonariensis (Valenciennes, 1835) broodstock age on gamete quality, reproductive performance and plasma sex steroid levels during the spawning season. Aquaculture Research, vol. 47, no. 3, pp. 969-982. http:// dx.doi.org/10.1111/are.12555

ELISIO, M., CHALDE, T. and MIRANDA, L., 2014. Seasonal changes and endocrine regulation of pejerrey (Odontesthes bonariensis) oogenesis in the wild. Comparative Biochemistry and Physiology. Part A, Molecular \& Integrative Physiology, vol. 175, pp. 102-109. http://dx.doi.org/10.1016/j.cbpa.2014.05.020. PMid:24892730.

ELISIO, M., VITALE, A. and MIRANDA, L.A., 2015. Influence of climate variations on Chascomús shallow lake thermal conditions and its consequences on the reproductive ecology of the Argentinian Silverside (Odontesthes bonariensis Actinopterygii, 
Atherinopsidae). Hydrobiologia, vol. 752, no. 1, pp. 155-166. http://dx.doi.org/10.1007/s10750-014-1945-y.

EL-SAYED, A.M. and KAWANNA, M., 2007. Effects of photoperiod on growth and spawning efficiency of Nile tilapia (Oreochromis niloticus L.) broodstock in a recycling system. Aquaculture Research, vol. 38, no. 12, pp. 1242-1247. 10.1111/j.1365-2109.2007.01690.x.

ESCALANTE, A.H., 1983. Contribución al conocimiento de las relaciones tróficas de peces de agua dulce del área platense. Otros Tetragonopteridae. Limnobios, vol. 2, no. 6, pp. 379-402.

ESCALANTE, A.H., 1987. Dieta comparativa de Cheirodon interruptus (Osteichthyes, Characidae) en ambientes lénticos y lóticos de la provincia de Buenos Aires. Revista del Museo de La Plata, vol. 152, pp. 35-45.

FERRIZ, R.A., BENTOS, C.A., FERNÁNDEZ, E.M. and LÓPEZ, G.R., 2011. Reproducción y dinámica poblacional de Cheirodon interruptus (Ostariophysi: Characidae) en el arroyo El Portugués, alta cuenca del río Samborombón, Argentina. Latin American Journal of Aquatic Research, vol. 39, no. 1, pp. 151-160. http://dx.doi.org/10.3856/vol39-issuel-fulltext-14.

GINÉS, R., AFONSO, J.M., ZAMORANO, M.J. and LOPEZ, J.L., 2004. The effects of long-day photoperiod on growth, body composition and skin colour in immature gilthead sea bream (Sparus aurata L.). Aquaculture Research, vol. 35, no. 13, pp. 1207-1212. http://dx.doi.org/10.1111/j.1365-2109.2004.01126.x.

GROSMAN, F. 2001. Fundamentos biológicos, económicos y sociales para una correcta gestión del recurso pejerrey. Argentina: Astyanax Buenos Aires, $246 \mathrm{p}$.

HANSEN, T., KARLSEN, O., TARANGER, G.L., HEMRE, G.I., HOLM, J.C. and KJESBU, O.S., 2001. Growth, gonadal development and spawning time of Atlantic cod (Gadus morhua) reared under different photoperiods. Aquaculture (Amsterdam, Netherlands), vol. 203, no. 1-2, pp. 51-67. http://dx.doi.org/10.1016/ S0044-8486(01)00610-X.

HUED, A.C. and BISTONI, M.D.L.Á., 2005. Development and validation of a biotic index for evaluation of environmental quality in the central region of Argentina. Hydrobiologia, vol. 543, no. 1, pp. 279-298. http://dx.doi.org/10.1007/s10750-004-7893-1.

JOURDAN, S., FONTAINE, P., BOUJARD, T., VANDELOISE, E., GARDEUR, J.N., ANTHOUARD, M. and KESTEMONT, P., 2000. Influence of daylength on growth, heterogeneity, gonad development, sexual steroid and thyroid levels, and $\mathrm{N}$ and $\mathrm{P}$ budgets in Perca fluviatilis. Aquaculture (Amsterdam, Netherlands), vol. 186, no. 3-4, pp. 253-265. http://dx.doi.org/10.1016/S00448486(99)00357-9.

KISSIL, G.W., LUPATSCH, I., ELIZURE, A. and ZOHAR, Y., 2001. Long photoperiod delayed spawning and increased somatic growth in gilthead seabream (Sparus aurata). Aquaculture (Amsterdam, Netherlands), vol. 200, no. 3-4, pp. 363-379. http:// dx.doi.org/10.1016/S0044-8486(01)00527-0.

KUCHARCZYK, D., TARGOŃSKA, K., HLIWA, P., GOMUŁKA, P., KWIATKOWSKI, M., KREJSZEFF, S. and PERKOWSKI, J., 2008. Reproductive parameters of common carp (Cyprinus carpio L) spawners during natural season and out-of-season spawning. Reproductive Biology, vol. 8, no. 3, pp. 285-289. http://dx.doi.org/10.1016/S1642-431X(12)60018-7. PMid:19092989.

LAMPERT, V.R., AZEVEDO, M.A. and FIALHO, C.B., 2007. Reproductive biology of Bryconamericus stramineus Eigenmann,
1908 (Ostariophysi: Characidae) from the Rio Ibicuí, RS, Brazil. Brazilian Archives of Biology and Technology, vol. 50, no. 6, pp. 995-1004. http://dx.doi.org/10.1590/S1516-89132007000700011.

LE CREN, E.D., 1951. The length weight relationship and seasonal cycle in gonad weight and condition in the perch Perca fluviatilis. Journal of Animal Ecology, vol. 20, no. 2, pp. 201-219. http:// dx.doi.org/10.2307/1540.

LOPEZ CAZORLA, A. and SIDORKEWICJ, N.S., 2005. Edad y crecimiento de Cheirodon interruptus (Characiformes: Tetragonopteridae) en la cuenca alta del Río Sauce Grande, Provincia de Buenos Aires. Biologia Acuatica, vol. 22, pp. 189-196.

LUBZENS, E., YOUNG, G., BOBE, J. and CERDA, J., 2010. Oogenesis in teleosts: how fish eggs are formed. General and Comparative Endocrinology, vol. 165, no. 3, pp. 367-389. http:// dx.doi.org/10.1016/j.ygcen.2009.05.022. PMid:19505465.

MAIZTEGUI, T., CAMPANELLA, D. and COLAUTTI, D.C., 2009. Avances en el desarrollo de la mojarra (Cheirodon interruptus) como alternativa a la explotación de poblaciones silvestres. Biologia Acuatica, vol. 26, pp. 143-149.

MIGAUD, H., FONTAINE, P., KESTEMONT, P., WANG, N. and BRUN-BELLUT, J., 2004. Influence of photoperiod on the onset of gonadogenesis in Eurasian perch Perca fluviatilis. Aquaculture (Amsterdam, Netherlands), vol. 241, no. 1-4, pp. 561-574. http://dx.doi.org/10.1016/j.aquaculture.2004.07.031.

MIRANDA, L.A., STRÜSSMANN, C.A. and SOMOZA, G.M., 2009. Effects of light and temperature conditions on the expression of $\mathrm{GnRH}$ and $\mathrm{GtH}$ genes and levels of plasma steroids in Odontesthes bonariensis females. Fish Physiology and Biochemistry, vol. 35, no. 1, pp. 101-108. http://dx.doi. org/10.1007/s10695-008-9232-3. PMid:19189237.

MOREHEAD, D.T., RITAR, A.J. and PANKHURST, N.W., 2000. Effect of consecutive 9- or 12-month photothermal cycles and handling on sex steroid levels, oocyte development, and reproductive performance in female striped trumpeter Latris lineata (Latrididae). Aquaculture (Amsterdam, Netherlands), vol. 189, no. 3-4, pp. 293-305. http://dx.doi.org/10.1016/S00448486(00)00371-9.

NORBERG, B., BJÖRNSSON, B.T. and HAUX, C. 1995. Photoperiod controls the timing of reproduction in Atlantic cod (Gadus morhua). In: F.W. GOETZ and P. THOMAS, ed. Proceedings of the 5th International Symposium on the Reproductive Physiology of Fish. Texas: The University of Texas at Austin. Fish Symposium, no. 95.

NORBERG, B., BROWN, C.L., HALLDORSSON, O., STENSLAND, K. and BJÖRNSSON, B.T., 2004. Photoperiod regulates the timing of sexual maturation, spawning, sex steroid and thyroid hormone profiles in the Atlantic cod (Gadus morhua). Aquaculture (Amsterdam, Netherlands), vol. 229, no. 1-4, pp. 451-467. http://dx.doi.org/10.1016/S0044-8486(03)00393-4.

OLIVEIRA, C.L.C., FIALHO, C.B. and MALABARBA, L.R., 2010. Reproductive period, fecundity and histology of gonads of two cheirodontines (Ostariophysi: Characidae) with different reproductive strategies insemination and external fertilization. Neotropical Ichthyology, vol. 8, no. 2, pp. 351-360. http://dx.doi. org/10.1590/S1679-62252010000200014.

PANKHURST, N.W. and PORTER, M.J.R., 2003. Cold and dark or warm and light: variations on the theme of environmental control of reproduction. Fish Physiology and Biochemistry, vol. 28, no. 1-4, pp. 385-389. http://dx.doi.org/10.1023/B:FISH.0000030602.51939.50. 
RAD, F., BOZAOĞLU, S., GÖZÜKARA, S.E., KARAHAN, A. and KURT, G., 2006. Effects of different long-day photoperiods on somatic growth and gonadal development in Nile tilapia (Oreochromis niloticus L.). Aquaculture (Amsterdam, Netherlands), vol. 255, no. 1-4, pp. 292-300. http://dx.doi.org/10.1016/j. aquaculture.2005.11.028.

SENDRA, E.D. and FREYRE, L.R., 1981a. Estudio demográfico de Cheirodon interruptus interruptus (pisces Tetragonopteridae) de la Laguna de Chascomús. I Crecimiento. Limnobios, vol. 2, no. 2, pp. 111-126.

SENDRA, E.D. and FREYRE, L.R., 1981b. Estudio demográfico de Cheirodon interruptus interruptus (pisces Tetragonopteridae) de la Laguna de Chascomús. II. Supervivencia y evaluación de modelos demográficos. Limnobios, vol. 2, no. 2, pp. 265-272.

TARANGER, G.L., AARDAL, L., HANSEN, T. and KJESBU, O.S., 2006. Continuous light delays sexual maturation and increases growth of Atlantic cod (Gadus morhua L.) in sea cages. ICES
Journal of Marine Science, vol. 63, no. 2, pp. 365-375. http:// dx.doi.org/10.1016/j.icesjms.2005.10.014.

TAYLOR, J. and MIGAUD, H., 2009. Timing and duration of constant light affects rainbow trout (Oncorhynchus mykiss) growth during autumn-spring grow-out in freshwater. Aquaculture Research, vol. 40, no. 13, pp. 1551-1558. http://dx.doi.org/10.1111/j.13652109.2009.02260.x.

TRIPPEL, E.A. and NEIL, S.R., 2003. Effects of photoperiod and light intensity on growth and activity of juvenile haddock (Melanogrammus aeglefinus). Aquaculture (Amsterdam, Netherlands), vol. 217, no. 1-4, pp. 633-645. http://dx.doi.org/10.1016/S00448486(02)00198-9.

ZHU, D.M., YANG, K., GUL, Y., SONG, W., ZHANG, X. and WANG, W., 2014. Effect of photoperiod on growth and gonadal development of juvenile Topmouth Gudgeon Pseudorasbora parva. Environmental Biology of Fishes, vol. 97, no. 2, pp. 147156. http://dx.doi.org/10.1007/s10641-013-0133-7. 